\title{
Sap flow index as an indicator of water storage use
}

\author{
Nadezhda Nadezhdina ${ }^{1 *}$, Jan Čermák ${ }^{1}$, Alec Downey ${ }^{2,3}$, Valeriy Nadezhdin $^{1}$, Martti Perämäki ${ }^{4}$, \\ Jorge Soares David ${ }^{5,6}$, Clara A. Pinto ${ }^{7}$, Teresa Soares David ${ }^{6,7}$ \\ ${ }^{1}$ Mendel University, Zemedelska 3, 61300 Brno, Czech Republic. \\ ${ }^{2}$ ICT International Pty Ltd, PO Box 503 Armidale NSW 2350, Australia. \\ ${ }^{3}$ School of Plant Biology, Botany, Horticulture and Hydrology, University of Western Australia, Crawley, Australia. \\ ${ }^{4}$ University of Helsinki, Yliopistonkatu 4, 00100 Helsinki, Finland. \\ ${ }^{5}$ Instituto Superior de Agronomia, Universidade de Lisboa, Tapada da Ajuda, 1349-017 Lisboa, Portugal. \\ ${ }^{6}$ Centro de Estudos Florestais, Universidade de Lisboa, Tapada da Ajuda, 1349-017 Lisboa, Portugal. \\ ${ }^{7}$ Instituto Nacional de Investigação Agrária e Veterinária I.P., Quinta do Marquês, Av. da República, 2780-159 Oeiras, Portugal. \\ ${ }^{*}$ Corresponding author. Tel: +420 545134 181. E-mail: nadezdan@mendelu.cz
}

\begin{abstract}
Symmetrical temperature difference also known as the sap flow index (SFI) forms the basis of the Heat Field Deformation sap flow measurement and is simultaneously collected whilst measuring the sap flow. SFI can also be measured by any sap flow method applying internal continuous heating through the additional installation of an axial differential thermocouple equidistantly around a heater. In earlier research on apple trees SFI was found to be an informative parameter for tree physiological studies, namely for assessing the contribution of stem water storage to daily transpiration. The studies presented in this work are based on the comparative monitoring of SFI and diameter in stems of different species (Pseudotsuga menziesii, Picea omorika, Pinus sylvestris) and tree sizes. The ability of SFI to follow the patterns of daily stem water storage use was empirically confirmed by our data. Additionally, as the HFD multipointsensors can measure sap flow at several stem sapwood depths, their use allowed to analyze the use of stored water in different xylem layers through SFI records. Radial and circumferential monitoring of SFI on large cork oak trees provided insight into the relative magnitude and timing of the contribution of water stored in different sapwood layers or stem sectors to transpiration.
\end{abstract}

Keywords: Diameter fluctuation; Heat field deformation; Multi-point sensor; Symmetrical temperature difference; Radial and circumferential variations; Sap flow measurement; Tree; Transpiration.

\section{INTRODUCTION}

Sap flow methodology is widely used in plant physiological, ecological and hydrological studies (Cermak et al., 1982; Granier et al., 1994; Hatton et al., 1990). Several sap flow methods were originally developed to measure high flows to understand the hydrological behavior of trees, stands and catchments (Cermak et al., 1973; Granier, 1985; Green and Clothier, 1988; Kučera et al., 1977). Later on, the comprehension of the relevance of low and bidirectional flow measurements for plant survival was revealed and new sap flow methods appeared (Burgess et al., 2001; Nadezhdina et al., 1998). Gradual improvement of physiological methodology is important for the understanding of interactions between vegetation and hydrology.

Besides direct sap flow measurements, also raw symmetrical temperature difference ( $d T_{\text {sym }}$ - so called sap flow index, SFI) proved to be valuable for physiological studies, namely as a water stress indicator (Nadezhdina, 1988, 1999). SFI is measured by two thermometers (differential thermocouples or thermistors) inserted in sapwood equidistantly in the axial direction in relation to a heater. During cloudless days, SFI showed an 'unusual' pattern (Nadezhdina, 1999) with two daily maxima, one in the morning and another in the evening, with a midday depression in between (McDonalds pattern). In earlier long-term research on apple trees (Nadezhdina, 1988, 1999), the midday SFI values $\left(\mathrm{SFI}_{\mathrm{d}}\right)$ showed a rather stable low threshold value over the growing season, whereas the night or predawn values $\left(\mathrm{SFI}_{\mathrm{p}}\right)$ varied widely, being usually low in wet days and high in dry days. Beyond, the period between the morning and evening SFI maxima provides complementary information on tree water status, increasing with drought. The ratio of predawn to midday SFI values (SFI ratio $=\mathrm{SFI}_{\mathrm{p}} / \mathrm{SFI}_{\mathrm{d}}$ ) was found to be a sensitive indicator of plant water status, and hence was successfully used in the automatic control of irrigation of an apple orchard (Nadezhdina, 1988, 1989, 1999). López-Bernal et al. (2010) and Ballester et al. (2013) based on experiments on olive and citrus trees, respectively, suggested that the proportion of nocturnal to diurnal sap flow (N/D index) might also be used as a sensitive tree water status indicator. However, the SFI ratio seems to be more sensitive than the N/D index (Nadezhdina, 2000).

SFI could be measured by any sap flow method applying internal continuous heating by the additional installation of the axial differential thermocouple equidistantly around a heater. However, the easiest solution is the application of the HFD methodology, where SFI is part of raw data records (Fig. 1).

Another important but not well known feature of the SFI is its empirical relationship with daily stem diameter (D) fluctuations which was observed for the first time in apple trees (Nadezhdina, 1988, 2009). A direct proportionality between SFI and D was found during daily stem shrinkage and an inverse proportionality during night refilling. The time interval between the two SFI maxima characterizes the period during which stem tissues dehydrate, due to the use of internal water storage through transpiration. The modelling of the contribution of the stem water reserves to plant water use (transpiration), according to Katerji and Hallaire (1984), also showed that water storage use occurred during the period of SFI daily depression, i.e., between its two daily maxima (Nadezhdina, 1992). Nadezhdina (1992) reported, for the first time, the possibility of using SFI to assess the relative contribution of stem water storage to daily transpiration without needing stem diameter measurements. 


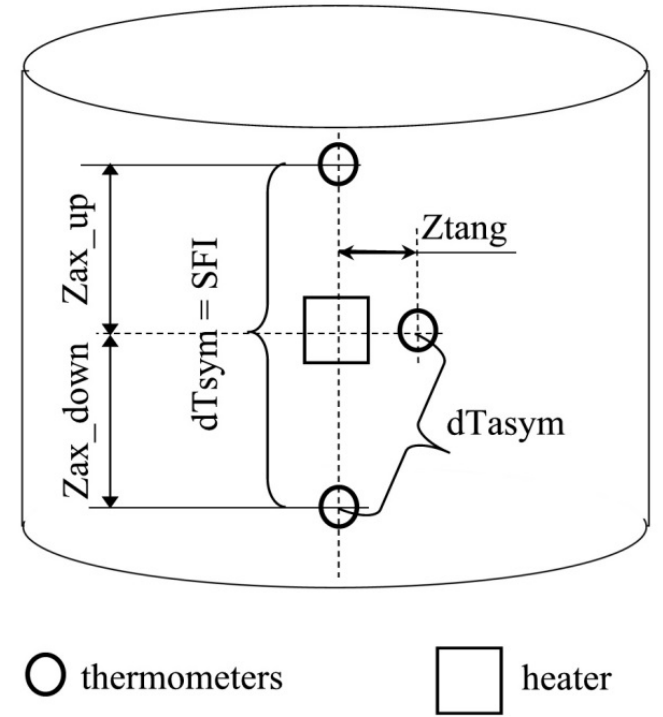

Fig. 1. Scheme of HFD sensor, consisting of three thermometers (circles) measuring deformation of heat field around a linear heater (square). Temperature difference measured by the two thermometers equidistantly disposed in axial direction (Zax_up $=$ Zax_down) represents dTsym or sap flow index (SFI).

During a period of increasing drought, Nadezhdina (1992) found that the time interval between daily SFI maxima and the daily depletion in SFI also increased, allowing the timing and the relative use of stem water storage to be assessed through SFI monitoring (Fig. 2). This direct correlation between the use of stem water storage and SFI has significant practical implications since SFI measurements are much simpler to perform than stem diameter measurements. Furthermore, the ability to measure SFI at several depths, radially across the sapwood using multipoint Heat Field Deformation (HFD) sensors (Nadezhdina et al., 1998), may reveal the contribution of water stored in different xylem layers and stem sectors to the overall daily water use.

Given the performance of the SFI in studying the water relations in apple trees (though empirical) we hypothesized that it might also be valuable to assess the relevance of stem water storage to water use in other species. We aimed to: (1) demonstrate the ability of SFI to follow the patterns of daily stem water storage use in different species and tree sizes and (2) demonstrate how the use of water storage may vary radially and circumferentially in tree stems.

\section{MATERIALS AND METHODS \\ Experimental sites and plant material}

Data reported in this study refer to research carried out at different sites on coniferous and broadleaved species: a Douglas fir tree (Pseudotsuga menziesii) at the Wind River experimental site $\left(45^{\circ} 49^{\prime} \mathrm{N}, 121^{\circ} 57^{\prime} \mathrm{W}\right)$, Washington, USA; a Scots pine tree (Pinus sylvestris L.) at the Hyytiälä station $\left(61^{\circ} 51^{\prime} \mathrm{N}, 24^{\circ} 17^{\prime} \mathrm{E}\right)$, southern Finland; a Spruce tree (Picea omorika) in Obora $\left(49^{\circ} 27^{\prime} \mathrm{N}, 16^{\circ} 36^{\prime} \mathrm{E}\right)$, Czech Republic; and two cork oak trees (Quercus suber L.) nearby Lisbon (3850`N, $8^{\circ} 49^{\prime} \mathrm{W}$ ), Portugal. Biometric data of these trees and site characteristics (soil type and climatic features) are given in Table 1.

\section{Sap flow measurements}

Sap flow was measured by the Heat Field deformation (HFD) method (Nadezhdina et al., 1998, 2012) in all trees except in the Douglas fir, where the Tissue Heat Balance (THB) method (Čermák et al., 1973; Kučera et al., 1977) was used.

The Heat Field Deformation technique was deployed using instruments with multipoint needles that were configured with measurement points at different spacing. This optimized the spatial resolution radially across the actively conducting xylem for each species. In Scots pine (Finland) six-point needles with $6 \mathrm{~mm}$ spacing were used; in cork oaks (Portugal) six-point needles with $8 \mathrm{~mm}$ spacing (Dendronet, Brno, Czech Republic); and in Spruce (Czech Republic) eight-point needles with $10 \mathrm{~mm}$ spacing (HFD8, ICT International Pty Ltd Armidale Australia). Considering that in this paper we aim to analyze the qualitative sap flow changes and its dynamics compared to those of SFI, sap flow per section, SFS, was directly used without further conversion to sap flow density to which it is directly proportional.

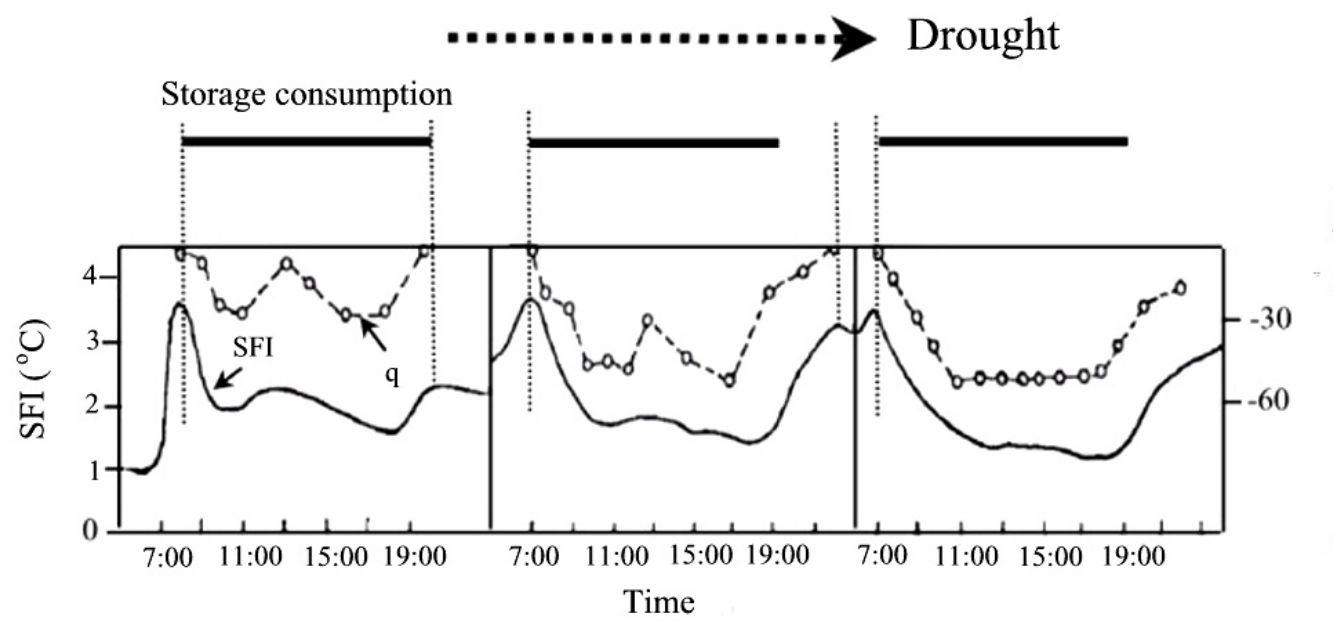

E
4
0
0
0
0
0
0
0
$\frac{\pi}{0}$
0
0
0
0

Fig. 2. Daily changes of sap flow index, SFI, measured at $0.5 \mathrm{~m}$ height in the stem of an apple tree (4 $\mathrm{m}$ height and $0.12 \mathrm{~m}$ diameter). Stem water use, q (storage, derived from measured leaf water potential and transpiration according to Katerji and Hallaire (1984)) and period between daily SFI maxima correspond well to each other. Dashed vertical lines limit the period of water consumption from stem storage, which increases with evaporative demand. The thick horizontal line, indicating the period of stem water use in the first day, is also plotted in the other two days to evidence the increase in stem water consumption as drought progresses. In the extremely hot day, shown in the last graph, the evening SFI maximum was not recorded till the end of the day. (Adapted from Nadezhdina (1992)). 
Table 1. Tree species, their biometrics and site characteristics.

\begin{tabular}{|l|l|l|l|l|l|l|}
\hline Tree species & $\begin{array}{l}\text { Common } \\
\text { name }\end{array}$ & $\begin{array}{l}\text { Tree } \\
\text { height } \\
(\mathrm{m})\end{array}$ & $\begin{array}{l}\text { Circumference } \\
\text { at breast height } \\
(\mathrm{m})\end{array}$ & $\begin{array}{l}\text { Sapwood } \\
\text { depth } \\
(\mathrm{m})\end{array}$ & $\begin{array}{l}\text { Soil type } \\
\text { Climate type } \\
\text { Average annual temperature } \\
\left({ }^{\circ} \mathrm{C}\right) \\
\text { Annual precipitation (mm) }\end{array}$ \\
\hline $\begin{array}{l}\text { Pseudotsuga } \\
\text { menziesii }\end{array}$ & Douglas fir & 57.0 & 4.05 & 0.070 & Entic dystrandepts & $\begin{array}{l}\text { Maritime Pacific } \\
8.7^{\circ} \mathrm{C} \\
2528 \mathrm{~mm}\end{array}$ \\
\hline Pinus sylvestris L. & Scots pine & 28.4 & 1.15 & 0.050 & Haplic Podzol & $\begin{array}{l}\text { Boreal } \\
4^{\circ} \mathrm{C} \\
700 \mathrm{~mm}\end{array}$ \\
\hline Picea omorica & Spruce & 4.5 & 0.28 & 0.043 & Cambisol & $\begin{array}{l}\text { Continental } \\
7.5^{\circ} \mathrm{C} \\
600 \mathrm{~mm}\end{array}$ \\
\hline $\begin{array}{l}\text { Quercus suber } \# 1 \\
\text { Quercus suber } \# 2\end{array}$ & Cork oak & 14.5 & 3.09 & 0.069 & Arenosol & $\begin{array}{l}\text { Mediterranean } \\
16^{\circ} \mathrm{C}, \\
622 \mathrm{~mm}\end{array}$ \\
\hline
\end{tabular}

The HFD sensors were installed at a height of $24 \mathrm{~m}$ on the eastern side of the Scots pine; at breast height $(1.3 \mathrm{~m})$ on the SW side of cork oak 1 and on the SE and the NW sides of cork oak 2; at $0.5 \mathrm{~m}$ height across the whole stem from western to eastern sides of spruce tree.

The THB method used five stainless steel $25 \times 1 \mathrm{~mm}$ rectangular electrodes that were inserted in parallel at $20 \mathrm{~mm}$ distances into the sapwood. Sensors were installed in 4 cardinal points at heights of $4 \mathrm{~m}$ and at $46 \mathrm{~m}$ sensors on two sides: southern and northern. The THB sap flow principle and measurements in Douglas fir are described in detail in Čermák et al. (2007).

\section{Sap flow index measurements}

The Sap Flow Index (SFI) was measured using the axial pair of differential thermocouples, arranged symmetrically in relation to a linear heater, inserted in the tree stem (Nadezhdina, 1998). This data forms the basis of the Heat Field Deformation sap flow measurements and was simultaneously collected by the HFD sensors whilst measuring the sap flow (see Fig. 1). Aiming to obtain SFI records from the THB method, the additional symmetrical pair of thermocouples was inserted $10 \mathrm{~mm}$ above and below the central electrode of the THB sensor into a depth of $15 \mathrm{~mm}$ below cambium.

\section{Stem diameter measurements}

Different methods were used to measure fluctuations in stem diameter (D).

In the Douglas fir tree, stem diameter was measured at the top $(46 \mathrm{~m}, \mathrm{~W})$ and base $(4 \mathrm{~m}, \mathrm{~S})$ of tree stem with a temperature compensated electronic radial dendrometer (DR-01, EMS Brno, Czech Republic). The bark was removed and smoothed to a distance about $1 \mathrm{~mm}$ from the bark cambium and phloem. A steel radial rod was inserted through a $7 \mathrm{~mm}$ diameter hole and screwed tightly into the heartwood. A magnetic sensor (Diana Inc., U.K.) was fastened to the rod. The sensitive point of the sensor was in direct contact with a smooth bark surface. The dendrometers were insulated and shielded similarly as the sap flow sensors. Stem diameter measurements for the Douglas-fir trees are described in detail in Čermák et al. (2007).

In the Scots pine tree, stem diameter was measured close to tree crown ( $24 \mathrm{~m}$ height) on the eastern stem side of the xylem surface, using linear variable displacement transducers (LVDT, model AX/5.0/S, Solartron Inc., Bognor Regis, U.K) attached to a rectangular metal frame mounted around the stem as performed by Perämäki et al. (2001) and Sevanto et al. (2002). The thermal expansions of wood and frame were taken into account.
Data were collected with a frequency of $2 / \mathrm{min}$.

In the Spruce tree, stem diameter was measured using the DEN5 Radial Arm Differential Dendrometer (ICT International Pty Ltd Armidale Australia). The DEN5 is a standalone logging dendrometer that uses two DVRT's, one positioned on a small exposed section of xylem and the other to a smoothed area of bark surface. Both are attached to a radial arm that is securely screwed into the heart wood of the tree via a $3 \mathrm{~mm}$ diameter hole drilled into the tree. The radial arm rod and mounting bracket are made from Invar a nickel-iron alloy with a low $\left(1.2 \times 10^{-6}\right)$ coefficient of thermal expansion $(\alpha)$ designed to minimize the impact of ambient thermal fluctuations. The DEN5 was installed on the northern side of the tree.

In the Douglas fir, Scots pine and Spruce trees, Sap Flow Index (SFI) and daily micro-variations in stem diameter were simultaneously measured either at the same tree height (spruce, Douglas fir) but at different stem sides or at the same side of tree with axial difference between SFI and D sensors around 30 $\mathrm{cm}$ (pine).

Stem diameter was not recorded in cork oak trees.

\section{RESULTS AND DISCUSSION Douglas fir tree}

Concurrent measurements of SFI and stem diameter (D), close to the crown, in the studied giant Douglas fir tree showed that the maximum SFI in the morning was synchronized with the maximum daily D (Fig. 3). After the peak, both SFI and D decreased. A 15 min lag was observed between the SFI maxima on the Southern and Northern sides of the tree (earlier on the Southern side). The daily SFI depletion was similar on the opposite sides, but predawn SFI was higher on the Southern side. Thus, the SFI ratio was higher on the Southern side of the trunk than on the Northern side, indicating higher tissue water deficit due to storage depletion in the Southern side. The decrease in the use of stored water in late afternoon (around 19:00 hours) was evidenced by the increase in SFI and D. The second daily SFI maximum was reached around midnight.

Stem diameter fluctuations at a height of $4 \mathrm{~m}$ were simultaneously measured with SFI at 4 different azimuths (cardinal directions). The morning increase of SFI occurred almost at the same time (at 8:15) on the Southern and Eastern sides of the tree, but half hour later on the Northern and Western sides (at 8:45) (Fig. 4). The morning SFI maximum measured at a height of $4 \mathrm{~m}$ lagged one hour behind that at the height of $46 \mathrm{~m}$ on the same side of the tree (at 7:15), indicating that the use of stored water in the sapwood of the tree is delayed at lower heights, or stratified within the tree. Čermák et al. (2007) also reported 


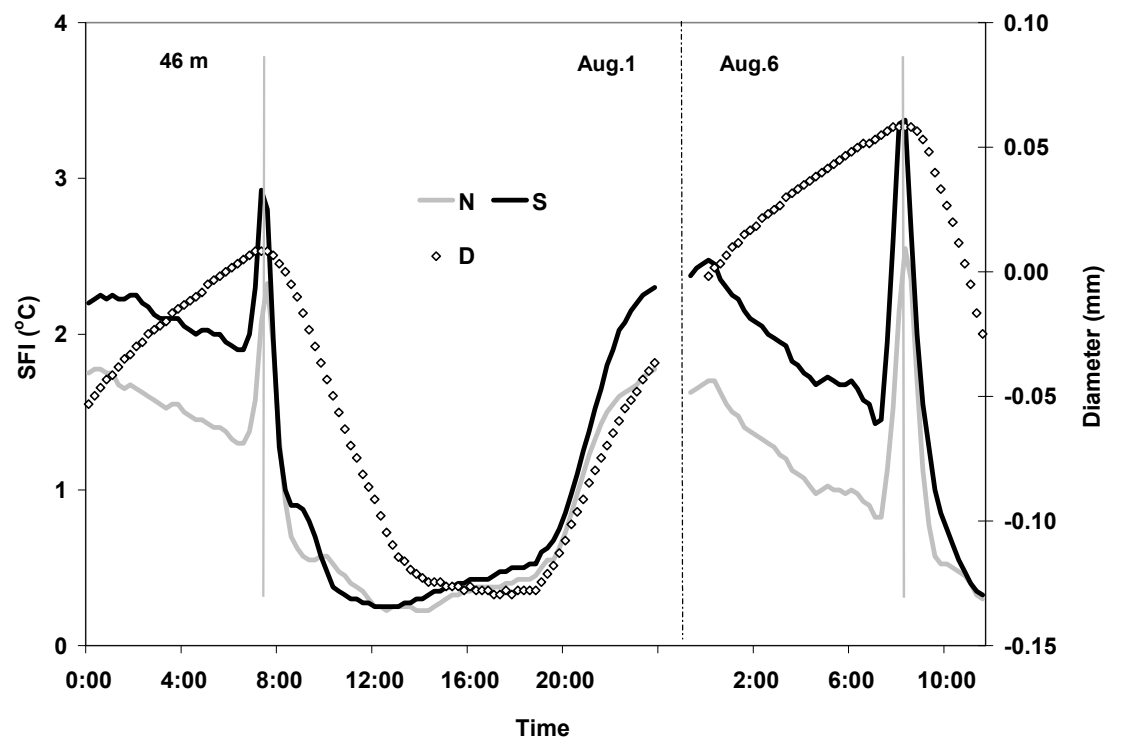

Fig. 3. Daily dynamics (August 1 and 6, 1996) of sap flow index (full lines) and stem diameter (D, open symbols) measured at $46 \mathrm{~m}$ height in a giant Douglas fir tree (Wind River, Washington, USA). SFI was measured on the S and N sides of the stem (black and grey lines, respectively). Grey vertical lines indicate morning SFI maximum (onset of water storage use).

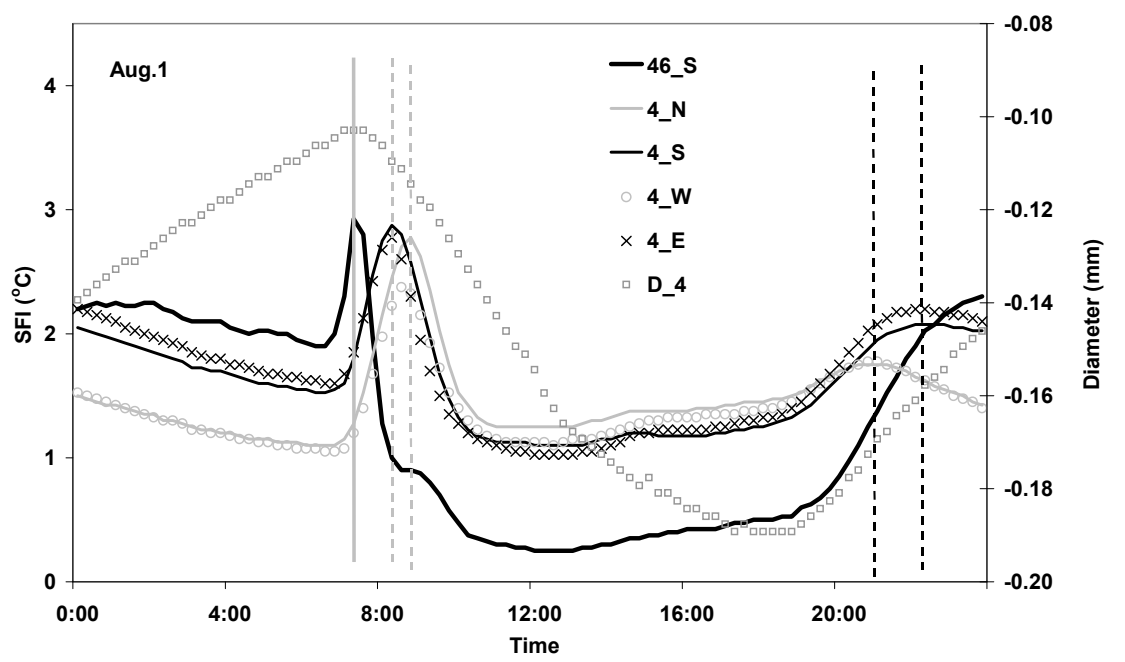

Fig. 4. Daily dynamics (August 1, 1996) of diameter, D, and sap flow index, SFI, in a giant Douglas fir tree at $4 \mathrm{~m}$ height (four different azimuths - N, E, S, W - thin black and grey lines and symbols) and at $46 \mathrm{~m}$ height at the S side of the tree (thick black line). Grey vertical lines indicate the morning SFI maximum (thick line - for height $46 \mathrm{~m}$ and thin dashed lines for $4 \mathrm{~m}$ height). Black dashed vertical lines indicate the evening SFI maximum for $4 \mathrm{~m}$ height.

a pronounced time shift between stem sap flow at heights of 51 $\mathrm{m}$ and at $4 \mathrm{~m}$ within the same tree. Sap flow measured at the base of the tree lagged behind that of the whole crown by 1 to $2 \mathrm{~h}$.

The evening SFI maxima were well defined at $4 \mathrm{~m}$ height, occurring about one hour and a half later at the Southern and Eastern sides, compared to the Northern and Western sides of the tree. Althougth daily SFI values were similar in all four sides of the tree at $4 \mathrm{~m}$ height, the predawn to midday SFI ratio was higher at the Southern and Eastern sides due to the higher night values. Results show that, at $4 \mathrm{~m}$ height, the use of water stored in the sapwood was larger at the Southern and Eastern sides than at the Western and Northern sides (larger period of daily SFI depletion and higher SFI ratio). These differences could not have been detected from stem diameter fluctuations alone. The comparison between SFI parameters (SFI ratio, period between daily maxima) at two tree heights shows lower water deficit and relative use of water stored in the xylem at $4 \mathrm{~m}$ than at $46 \mathrm{~m}$. Čermák et al. (2007) also reported that the upper part of the stem was subject to much greater desiccation than the lower part of the studied tree.

Sevanto et al. (2008) demonstrated that the simultaneous measurement of sap flow and diameter variation significantly increases the amount of information on water flow dynamics in stems, compared to what could be obtained by either method alone. This is evidenced in our study by the observed daily loops in the relation between diameter and SFI (Figure 5). The nighttime period of the loop gives information about stem growth and storage refilling from root uptake (black arrow), and the daytime period (grey arrows between morning and evening SFI maxima) indicates storage water use. The morning SFI maximum, due to its sharp and narrow habit, is especially convenient for the determination and characterization of separate growth periods (days, weeks, months etc. - see Fig. 4). This SFI chain diagram during the growing season gives unique, clear 


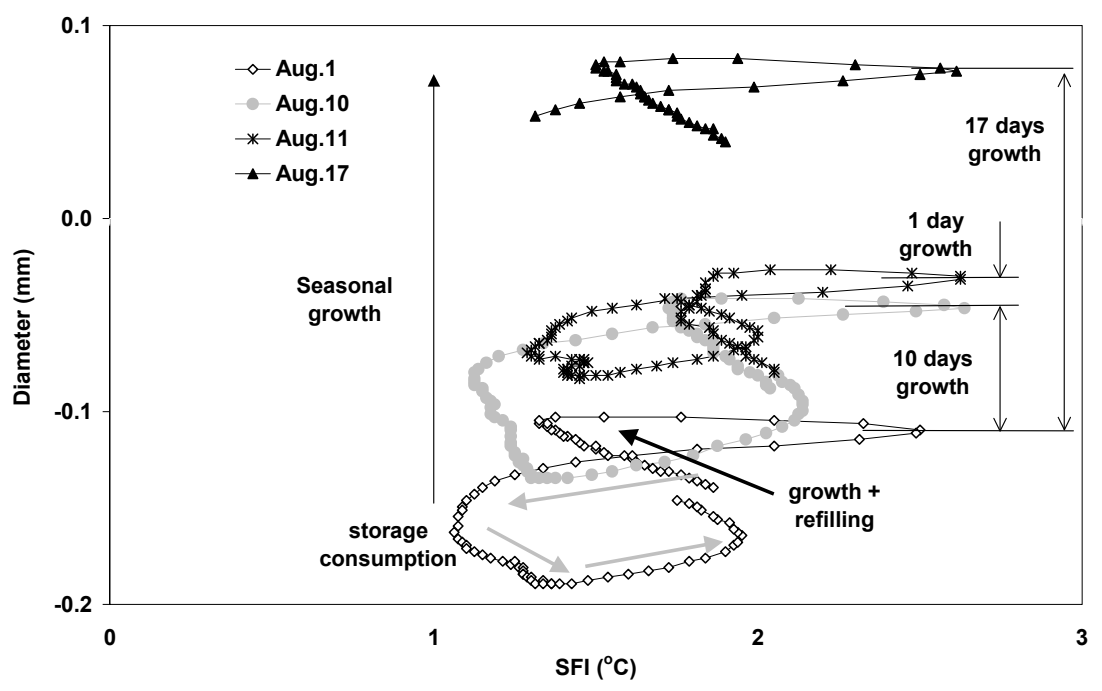

Fig. 5. Relationship between SFI (mean for sides $\mathrm{E}$ and W) and diameter of tree stem of Douglas fir at height of $4 \mathrm{~m}$ for several days of the observed period in August 1996. Each day is characterized by its specific " 8 -shape" curve, depending on environmental conditions. Full grey arrows correspond to the period of storage consumption during the day. Black arrow indicates the nighttime refilling period, due to root absorption, occurring after late evening (when storage use stopped). During the night both growth and tissue rehydration take place. Daily storage consumption can be evaluated independently from stem growth. Stem growth for the certain period is evaluated as a difference in diameter between the morning SFI maxima of corresponding days.

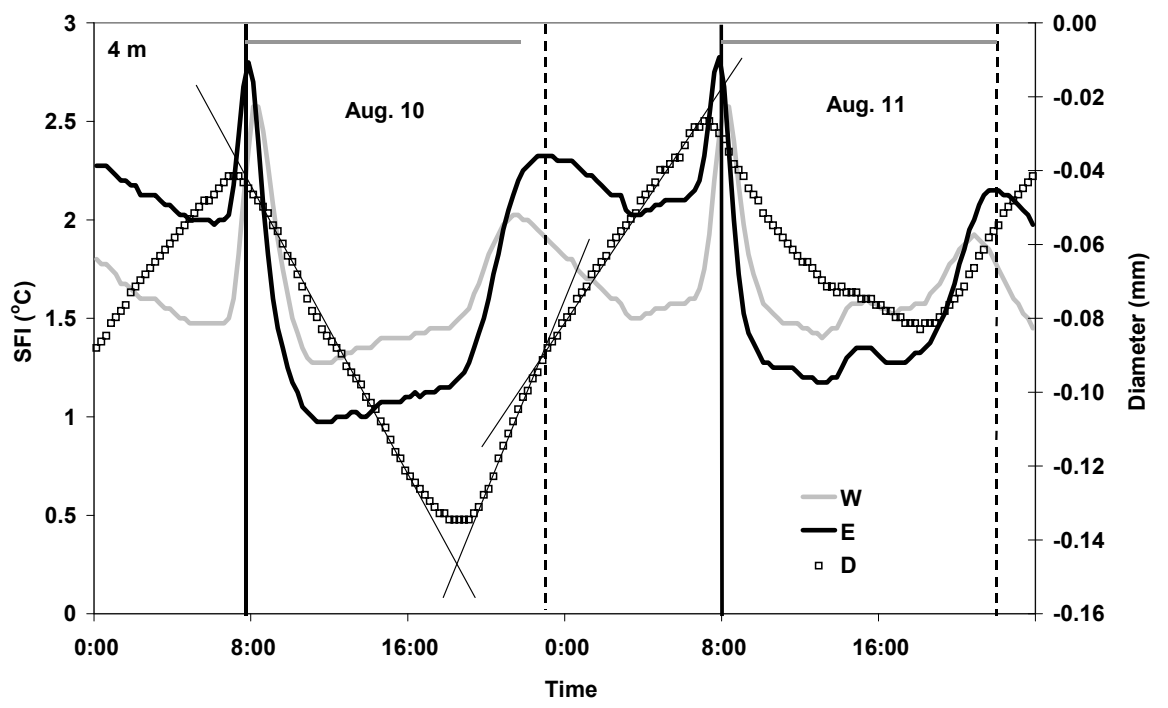

Fig. 6. Daily dynamics of sap flow index, SFI, and diameter, D, at $4 \mathrm{~m}$ height in a giant Douglas fir during sunny (August 10) and cloudy (August 11) days. SFI was measured from two opposite sides East (black) and West (grey). Full vertical lines indicate the period of the morning SFI maximum for the E side (recorded slightly earlier) and dashed vertical lines indicate the period of the evening SFI maximum for the E side (recorded later than on West side). Grey horizontal line (shown for both days) indicates the period between SFI maxima for the cloudy (August 11) day. This period was shorter than that of the sunny day (compare also with Figure 2). Inclined full thin lines separate different trends in diameter fluctuation after its morning maximum (see text for details).

information about tree water status and growth. It facilitates the analysis and interpretation of seasonal increment chronologies, allows the separation of the water-related from the growthrelated components of stem diameter changes, and improves knowledge on the relations between growth, plant physiology and ecohydrology (Ježík et al., 2007, 2011, 2014; Vieira et al., 2013; Wang et al., 2012; Zweifel et al., 2006). The daily storage loops and the night growth/refilling curves dynamically differ during the growing season, likely reflecting changes in evaporative demand and soil moisture conditions. Larger loops correspond to dryer conditions, when the diameter decreases and the daily amplitude of diameter variation increases
(Offenthaler et al., 2001; Sevanto et al., 2005). Previous studies suggested three general patterns related to dimensional changes of stem diameter in trees - (1) growth, (2) a mixture of growth and tissue rehydration, (3) only tissue rehydration (Hinckley and Bruckerhoff, 1975; Lassoie, 1979). The relation between SFI and D gives an immediate indication of the type of pattern and its occurrence within the growing season. Čermák et al. (2007) observed only pattern 2 in old-growth Douglas-fir trees. This is evident from Fig. 5 where clear positive diurnal changes in stem dimensions between morning SFI maxima were observed. No zero SFI was recorded at nights indicating substantial tissue rehydration additionally to night growth. 
In order to analyze the influence of evaporative demand on the behavior of SFI and D, two days with different climatic conditions were selected (one sunny day and one cloudy day). SFI from the Eastern and Western sides (stem sectors with different water storage use) were compared to the stem diameter fluctuations at a height of $4 \mathrm{~m}$ (Fig. 6). On the sunny day (August 10) diameter shrinkage was twice that of the cloudy day (August 11) - compare also daily loops in relationship between SFI and D for these days in Figure 5. Diameter depletion in August 10 was characterized by a linear decrease, whereas diameter increase towards the next maximum showed two periods with different slopes. The intercept between these two rising trends coincides with the SFI evening maxima from the Eastern side, when daily transpiration stopped. From this moment onwards, root water absorption (plus possible use of storage from lower stem and large roots) was no longer affected by transpiration representing a net storage refill. This shifting moment is usually difficult to distinguish from records of diameter fluctuations alone, but it is well defined by the evening maximum of SFI. Although predawn SFI in Aug. 11 was a bit higher than in Aug. 10, after a hot sunny day, daily storage use (marked by grey horizontal line in Fig. 6) was lower in the cloudy day due to lower evaporative demand. The lower storage use in the cloudy day, directly visible by the smaller daily loop in the relationship between SFI and D (see Fig. 5), is also evidenced through SFI records alone: lower daily depression of SFI, lower SFIp/SFId ratio (1.79 on Aug. 11 against 2.00 on Aug. 10), and 1 hour shorter time interval between daily SFI maxima on Aug. 11 (see Fig. 6).

\section{Scots pine tree}

In the pine tree, the best fit between the daily dynamics of SFI and D was observed at a height of $24 \mathrm{~m}$, i.e., closer to the tree top (Fig. 7). There was a clear direct proportionality $\left(\mathrm{R}^{2}=\right.$ $0.91)$ between daily SFI and diameter depletion between the two
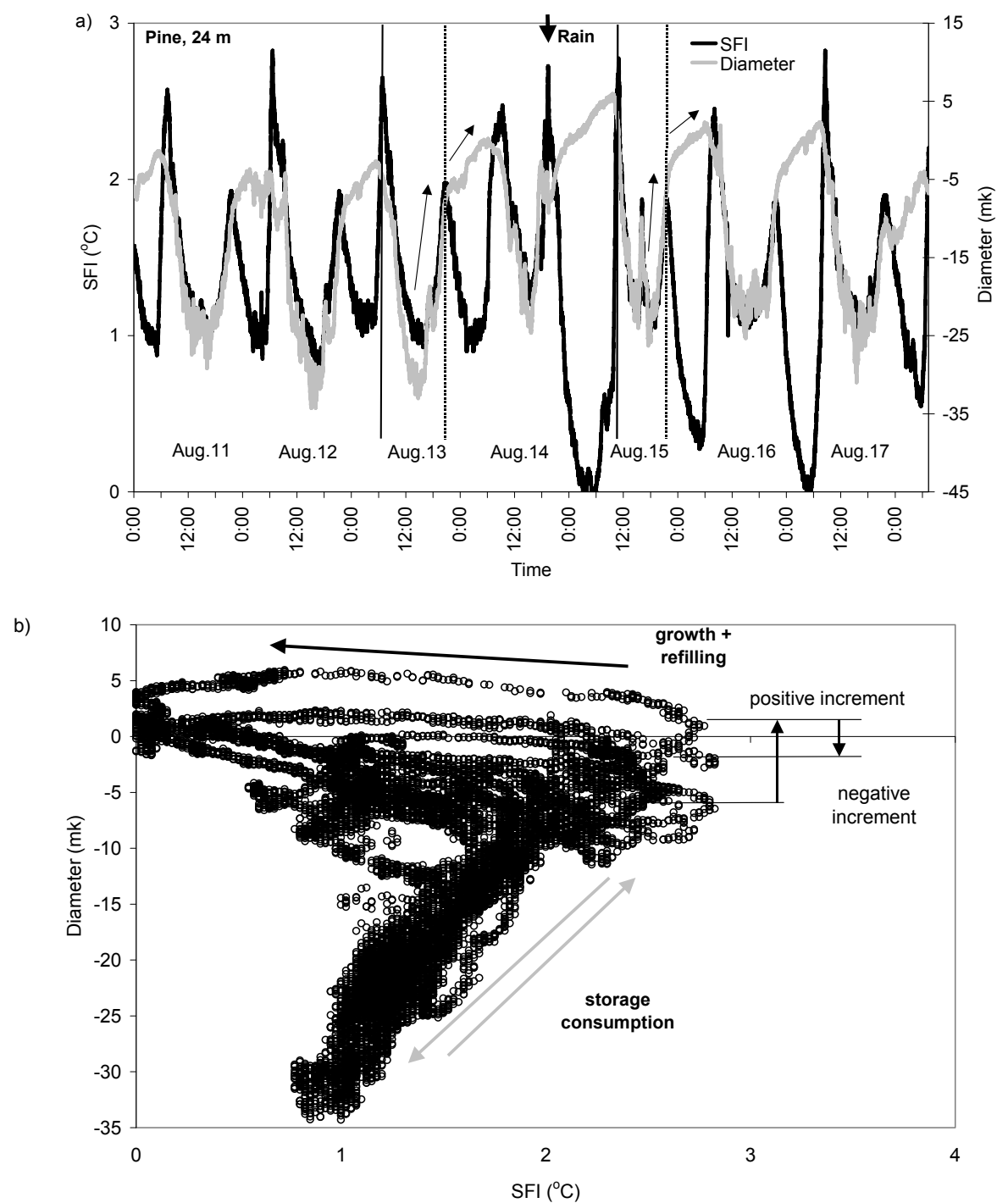

Fig. 7. a) Daily dynamics of SFI (black) and diameter (D, grey) in the stem of a Scots pine tree measured at $24 \mathrm{~m}$ stem height $(\mathrm{Rxyl}=7$ $\mathrm{cm}$ ) in August 11-18, 2002, during hot weather (SMEAR II station in Hyytiälä, Finland). Vertical lines indicate the SFI maxima: full line corresponds to morning maximum when storage starts to be used and dashed lines to the evening SFI maxima when storage use stops. Arrows show different trends in diameter variation, separating the period of storage use from that of storage refilling and growth.

b) Relationship between diameter and SFI for the period shown in the upper panel a). Grey arrows indicate the period of storage water use when SFI and D directly correlate $\left(\mathrm{R}^{2}=0.91\right)$. Black full arrow indicates the period of storage refilling and growth under inverse proportionality between SFI and D. Vertical arrows indicate positive or negative increments of stem diameter evaluated as a difference of diameter fluctuation between the morning SFI maxima of corresponding days. 
daily SFI maxima, and a reverse relation during nighttime refilling and growth (Fig. 7b). Similarly to Douglas fir (see Fig. 6), the onset of pine storage refilling occurred at the evening SFI maxima when the rate of diameter increase changed (see thin arrows in Fig. 7). The evening rain (Aug. 14) refilled stem tissue fast, as reflected by the quick decrease of night SFI values till zero. Differences in night tissue rehydrating are not evident from diameter fluctuations alone. We can also observe different night periods, between SFI maxima, even in similar days with full stem tissue rehydration by rain in evening (Aug. 14) or at night (Aug. 16): the evening SFI maximum recorded at 19:27 on Aug. 14 and at 21:51 on Aug. 16, whereas the morning SFI maximum in the following days occurred at 10:58 (Aug. 15 likely due to fog) and at 8:35 (Aug. 17). Larger night periods between SFI maxima (Aug. 14 and Aug. 15) facilitated higher stem growth, in correspondence with earlier findings, showing that wet conditions result in an increase in midnight diameter (Offenthaler et al., 2001; Sevanto et al., 2005). SFI results at only one measured depth $(0.8 \mathrm{~cm}$ below cambium) were analyzed here, but SFI trends in all five measured xylem layers was similar in the top of the pine tree where the xylem radius was small $(7 \mathrm{~cm})$. Differences were only observed in the magnitude of SFIp/SFId ratio which was lower for the inner stem xylem at the 3 and 3.6 cm depths.

When daily dynamics of sap flow, D and SFI of the observed period (see Fig. 7) were superimposed, a progressive increase in sensitivity (higher in SFI) of the measured parameters to changes in environmental conditions was observed (Figure 8).

a)

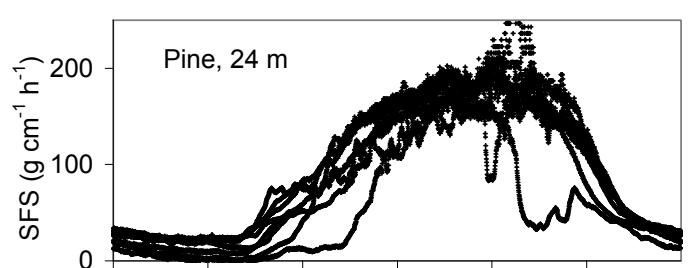

b)

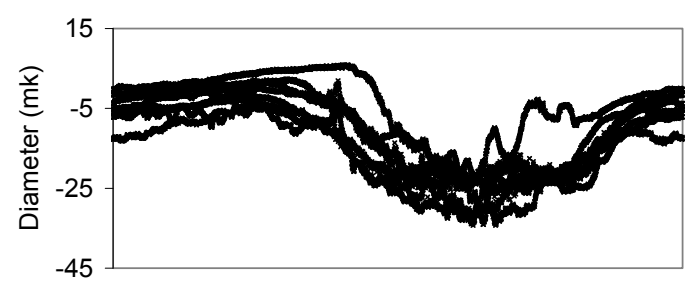

c)

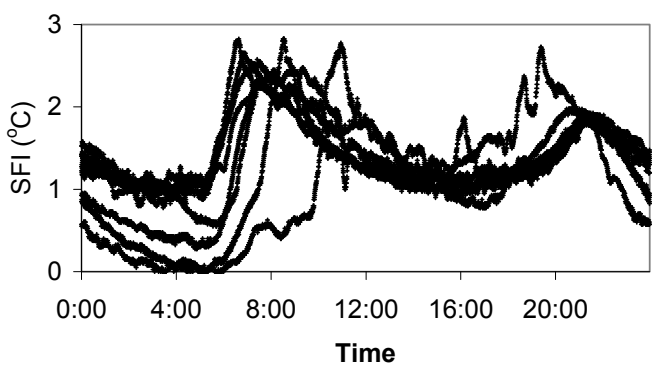

Fig. 8. Diurnal courses of sap flow (a), diameter fluctuation (b) and sap flow index (c) in pine stem at $24 \mathrm{~m}$ height for seven consecutive days of the period in Fig. 7, under different weather condition.

The relationship between SFI and D substantially differs between the small pine stem (Figure $7 \mathrm{~b}$, lower panel) and the huge stem of Douglas fir (see Fig. 5), mostly due to differences in species and tree size, as environmental conditions were similar (very hot) in both cases. No daily loops in storage depletion were observed in the pine tree, in contrast with Douglas fir. Due to very dry soil and hot weather conditions, high water deficits occurred in pine stem tissue (high night SFI and SFI ratio) before rain, reflected in low, zero or even negative night diameter increments which correspond to pattern 3 of dimensional changes in tree (only tissue rehydration - Hinckley and Bruckerhoff, 1975; Lassoie, 1979). More recently, a different terminology has been used to describe daily cycles of stem diameter variations, also divided in three phases: contraction (1), recovery (2) and radial increment (3) (Deslauriers et al., 2003, 2007, 2011; Devine and Harrington 2011; Downes et al., 1999; Vieira et al., 2013). This new approach aims to facilitate the analyses of large dendrometric datasets. The SFI chain diagram (see Figs. 5 and 7), may be a fast and easy way to distinguish the positive, zero or negative radial increment phases (Figure $7 b$ ). To our knowledge, SFI measurement is the only technique that allows to identify the time when storage usage ends and stem refilling begins (see Figs. 6 and 7a).

Results of the two analyzed conifers, of very different sizes, show that the relation between daily SFI depression and diameter shrinkage is stronger in smaller trees (pine) or at top of large trees.

\section{Spruce tree}

The diurnal trend of SFI was also similar in all xylem depths of a young spruce tree (10 years), where the HFD multi-point needles crossed the whole stem from the western to eastern side (Figure 9). But the level of water use from xylem storage was different from the Eastern to Western side of the tree, based on the SFIp/SFId ratio. According to the SFI records (which were never zero) the stem cross-section consists entirely of water conducting xylem or sapwood, with no heartwood. The correlation between SFI and D daily variations was lower than in pine, but still substantial $\left(\mathrm{R}^{2}=0.52\right)$. We should emphasize that in the pine tree both SFI and D were measured at the same stem side, whereas in spruce measurements were taken from different sides (east-west for SFI and north for D). This may possibly explain the lower correlation between studied parameters in spruce. Perämäki et al. (2001) and Zweifel et al. (2001) did not find differences in diameter variation between azimuths in the same tree, indicating fairly homogenous transpiration-induced pressure field inside the stem. Conversely, Sevanto et al. (2008) showed that differences in measurements of $\mathrm{D}$ at different azimuths can be significant if the tree crown or stem is asymmetric. In our case, the spruce tree had a symmetric crown, but was growing in a yard surrounded by walls at three cardinal points (north, east and south) which potentially could induce different water status at different tree sides.

In our rather short studies (several weeks), with synchronous measurements of SFI and D presented above (Douglas fir and pine), only growth (pattern 1 - Hinckley and Bruckerhoff, 1975; Lassoie, 1979) was never recorded because nighttime tissue rehydration was needed to restore storage used in daytime transpiration under hot sunny weather. However, this pattern can be observed after cloudy days with low transpiration, when water storage use does not occur and tree growth can take place during night without preliminary storage refilling. As we have been measuring sap flow and diameter fluctuation in spruce for a long-term (March 2013 till now), we chose it to present a period with cloudy days followed by improved weather (Fig. 9). Indeed, in the first three cloudy days (when neither D depletion,or typical SFI McDonnalds curves occurred) we observed night pattern 1 (only growth), followed by pattern 2 (tissue refilling plus growth) at nights after sunny days with diameter depletion between the two SFI maxima. 


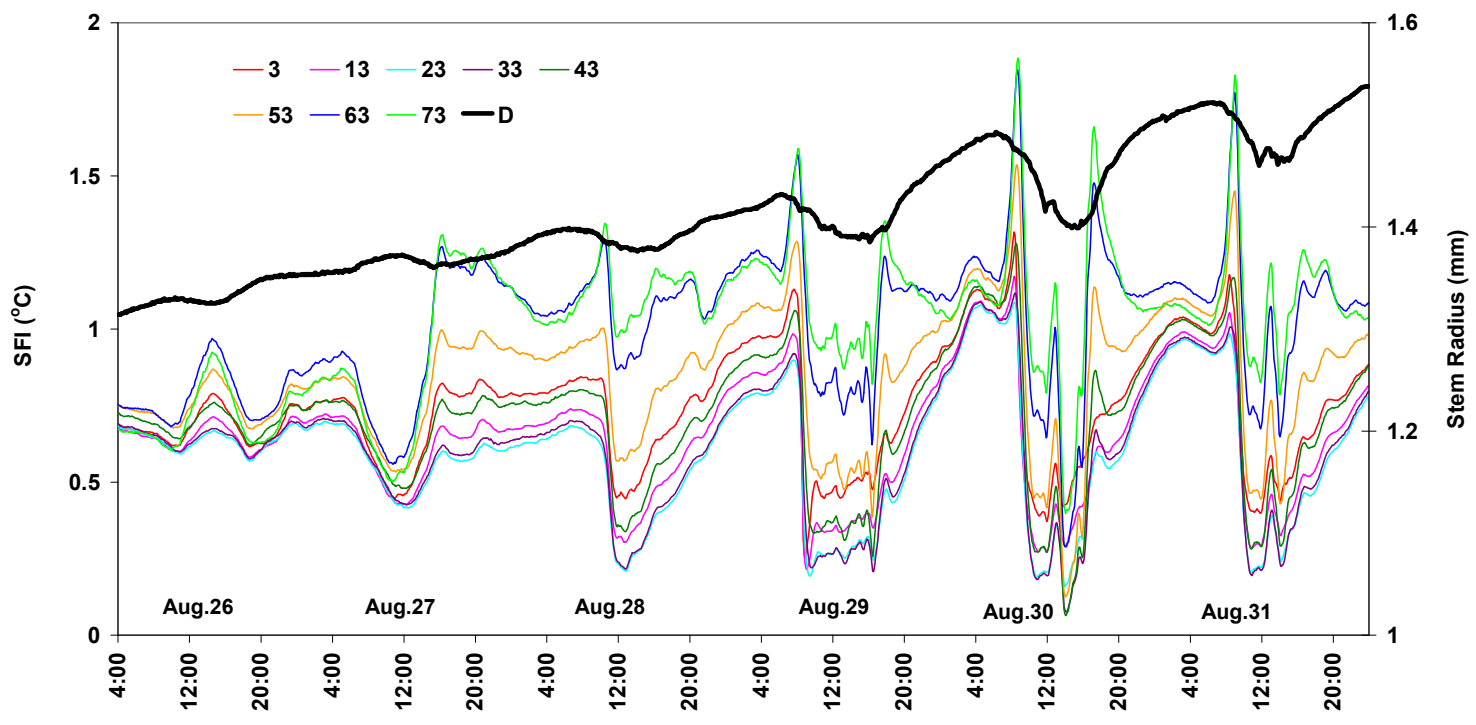

Fig. 9. Sap flow index at 8 depths below cambium (marked by numbers in $\mathrm{mm}$ in legend) and diameter (thick black line) in a spruce stem, measured in August of 2013 under different weather conditions (three cloudy days followed by two sunny days).

\section{Cork oak trees}

Contrary to what was observed in pine and spruce trees, SFI in large cork oak trees varied substantially between xylem layers (Fig. 10). Hence, the SFI may also provide insight into the relative magnitude and timing of the contribution to transpiration of water stored in different sapwood layers. Fig. 10 shows the variation in sap flow (SFS) and SFI from cambium to inner xylem (6 measuring points across the sapwood radius) of a cork oak tree stem (tree \#1). The highest sap flow rates were observed in the outer xylem (6 and $16 \mathrm{~mm}$ below cambium), which contributed to the higher amounts of used stored water (higher SFI ratio and higher time intervals between the two SFI maxima). The contribution of water storage to transpiration should decrease towards the inner xylem. An asynchronicity in the use of water stored in different xylem layers may suggest this and/or their connection to different foliage cohorts.

Moreover, SFI also provided information on nighttime storage refilling, as illustrated in Fig. 10, for two contrasting nights. During the first night (March 29), SFI was very high (especially in the outer xylem layers) due to nighttime transpiration (high wind velocity). In the following night (March 30) SFI was lower, due to lower wind velocity and higher air humidity, and refilling was gradual. Immediately before predawn, fast tissue replenishment mostly in the outermost xylem layers was observed, due to sudden high air humidity occurrence. Results show that SFI has a greater sensitivity than sap flow rates (SFS) at low flows.

When multipoint HFD needles are installed in different stem azimuths, SFI may also provide information on the use of water stored in stem sectors. In another cork oak tree (tree \#2) sap flow was measured at south-east and north-west azimuths (Fig. 11). Maximum flow was of the same magnitude at the SE and NW azimuths, with higher flows in the outer xylem. Flow peaked in the morning at the SE side, and in the afternoon at the NW side, reflecting sun positioning and the high sectoriality of the $Q$. suber tree (David et al. 2012). Accordingly, the afternoon SFI maximum occurred later at the NW side. The dynamics of SFI along the xylem radius, showed higher use of stored water and greater depletion in the NW than in the SE stem side. In spite of the rather similar sap flow values observed on Aug. 26 and Aug. 27, SFI substantially differed, indicating higher stor- age replenishment on Aug. 26, after a cloudy rainy day (Aug. $25)$. On this day, the use of stem water storage was very low (see lower and shorter daily SFI depression). Furthermore, the foggy weather in the morning of Aug. 26 sharpened the decrease of SFI in all sides what was not visible on SFS itself. As we see from Fig. 11, stem sectoriality (see David et al., 2012) may substantially influence circumferential and radial SFI variation.

Diurnal tree size fluctuations were thought to occur mainly in the elastic bark tissues, external to the rigid xylem (Arcikhovskiy, 1931; Hinckley and Bruckerhoff, 1975; Lassoie, 1979; Zweifel et al., 2000). Irvine and Grace (1997) demonstrated that the sapwood may also contribute to stem dimensional changes. Recently Zweifel et al. (2014) found, that diurnal size fluctuations of the rigid xylem in fast growing Eucalyptus globulus Labill are the main driver of total stem diameter

a)

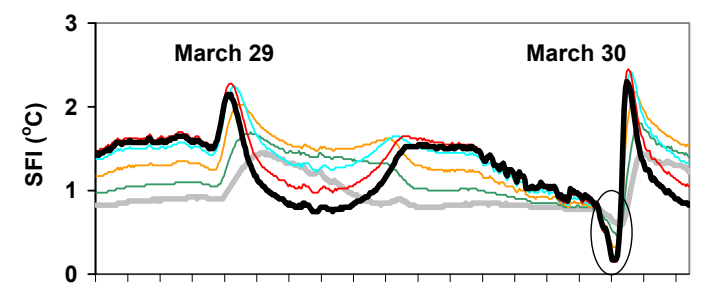

b)

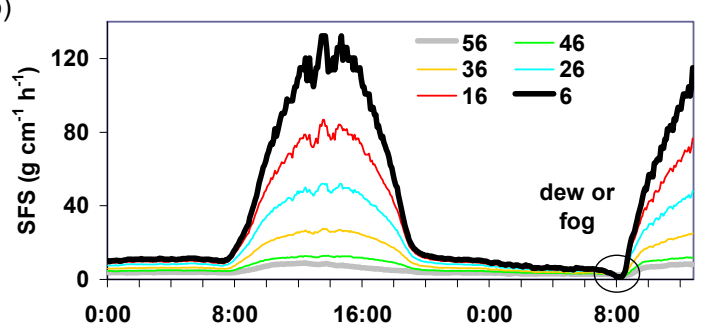

Fig. 10. Daily dynamics of sap flow index (SFI, (a)) and sap flow (SFS, (b)) in the stem of a cork oak tree (Portugal, 2007) measured in different xylem layers (depth below the cambium, $\mathrm{mm}$, is indicated in the legend). Thick lines underline the outer (black) and the inner (grey) sapwood depths. Ellipses show a short period with high air humidity at predawn (fog or dew). 
a)
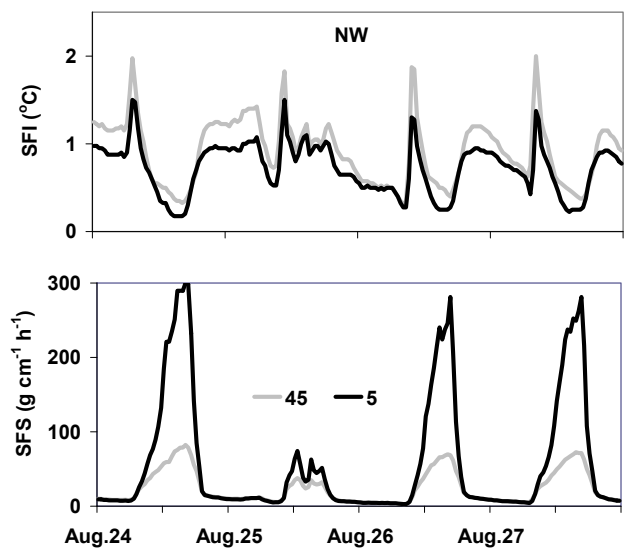
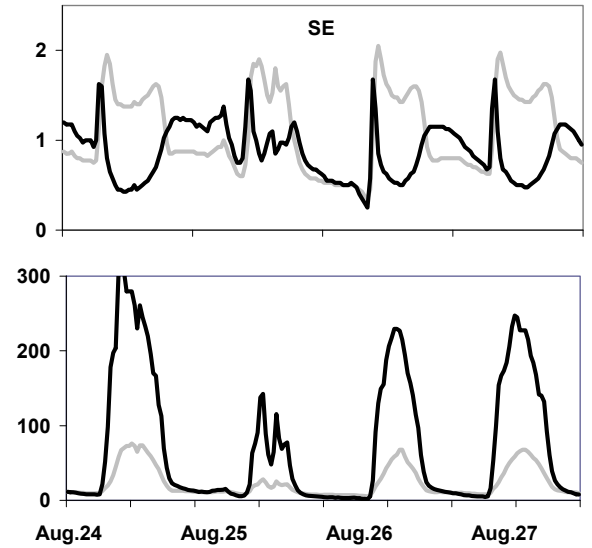

Fig. 11. Daily dynamics of sap flow index (SFI) and sap flow (SFS) in the trunk of a cork oak tree (Portugal, August 2007) measured in five different xylem layers at 2 different sides (SE (a) and NW (b)). For clarity only 2 depths are shown (depth below the cambium is indicated in the legend, mm): the outer (black) and the inner (gray).

changes. The authors connected their findings with the high wood elasticity of secondary thickening xylem. Other authors reported that most of the stored water comes from inelastic sapwood (Čermák et al., 2007; Waring and Running, 1978) - so called extracellular or capillary water. Holbrook (1995) stated that this "free“ water could represent a substantial fraction of water in trees. To our knowledge, nothing is known on how different xylem layers may contribute to stem water storage and on its use. Thus, our empirical studies represent a first insight on possible redistribution and variable dynamics of the stored water in stem xylem, needing further confirmation by other independent measurements.

\section{CONCLUSIONS}

Comparative studies of SFI and D in stems of different species and tree sizes confirmed the ability of SFI to follow the patterns of daily stem water storage used in transpiration. Analysis of SFI in different trees showed that the period between the two daily SFI maxima and the corresponding SFI daily depression are usually larger in the outer xylem (where also higher sap flow rates occur) compared to the inner xylem.

Radial and circumferential variations of SFI were observed, with higher differences in large stems. The use of the HFD method with sensors inserted at several depths in the stem sapwood proved to be an important tool to analyze the impact of different xylem layers and different stem sectors in the use of the stem water storage.

Acknowledgements. Writing of this paper was partially supported by the projects INVID CZ.1.07/2.3.00/20.0265 and IGALDF-73/2013.

\section{REFERENCES}

Arcikhovskiy, V.M., 1931. Suction of water by woody species under its artificial injection through holes in conducting tissues. Trudy polesnomu opytnomu delu, CLOS, XI, 69-141. (In Russian.)

Ballester, C., Castel, J., Testi, L., Intrigliolo, D.S., Castel, J.R, 2013. Can heat-pulse sap flow measurements be used as continuous water stress indicators of citrus trees? Irrig. Sci., 31, 1053-1063.
Burgess, S.S.O., Adams, M.A., Turner, N.C., Beverly, C.R., Ong, C.K., Khan, A.A.H., Bleby, T.M., 2001. An improved heat pulse method to measure low and reverse rates of sap flow in woody plants. Tree Physiol., 21, 589-598.

Čermák, J., Deml, M., Penka, M., 1973. A new method of sap flow rate determination in trees. Biol. Plant. (Praha), 15, 171-178.

Čermák, J., Úlehla, J., Kučera, J., Penka, M., 1982. Sap flow rate and transpiration dynamics in the full-grown oak (Quercus robur L.) in floodplain forest exposed to seasonal floods as related to potential evapotranspiration and tree dimensions. Biol. Plant. (Praha), 24, 446-460.

Čermák, J., Kučera, J., Bauerle, W.L., Phillips, N., Hinckley, T., 2007. Tree water storage and its diurnal dynamics related to sap flow and changes in stem volume in old-growth Douglas-fir trees. Tree Physiol., 27, 181-198.

David, T.S., David, J.S., Pinto, C.A., Čermák, J., Nadezhdin, V., Nadezhdina, N., 2012. Hydraulic connectivity from roots to branches depicted through sap flow: analysis on a Quercus suber tree. Funct. Plant Biol., 39, 103-115.

Deslauriers, A., Morin, H., Urbinati, C., Carrer, M., 2003. Daily weather response of balsam fir (Abies balsamea (L.) Mill.) stem radius increment from dendrometer analysis in the boreal forests of Quebec (Canada). Trees, 17, 477-484.

Deslauriers, A., Rossi, S., Anfodillo, T., 2007. Dendrometer and intra-annual tree growth: What kind of information can be inferred? Dendrochronol., 25, 113-124.

Deslauriers, A., Rossi, S., Turcotte, A., Morin, H., Krause, C., 2011. A three-step procedure in SAS to analyze the time series from automatic dendrometers. Dendrochronol., 29, 151161.

Devine, W.D., Harrington, C.A., 2011. Factors affecting diurnal stem contraction in young Douglas-fir. Agric. For. Meteorol., 151, 414-419.

Downes, G., Beadle, C., Worledge, D., 1999. Daily stem growth patterns in irrigated Eucalyptus globulus and E. nitens in relation to climate. Trees, 14, 102-111.

Granier, A., 1985. Une nouvelle methode pour la mesure dy flux de seve brute dans le trons des arbres. [A new method of sap flow measurement in tree stems]. Ann. Sci. For., 22, 193200. (In French.)

Granier, A., Anfodillo, T., Sabatti, M., Cochard, H., Dreyer, E., Tomasi, M.,Valentini, R., Breda, N., 1994. Axial and radial 
water flows in the trunks of oak trees: a quantitative and qualitative analysis. Tree Physiol., 14, 1383-1396.

Green, S.R., Clothier, B.E., 1988. Water use of kiwifruit vines and apple trees by the heat-pulse technique. J. Exp. Bot., 39, 115-123.

Hatton, T.J., Vatchpole, E.A., Vertessy, R.A., 1990. Integration of sap flow velocity to estimate plant water use. Tree Physiol., 6, 201-209.

Hinckley, T.M., Bruckerhoff, D.N., 1975. The effect of drought on water relations and stem shrinkage of Quercus alba. Can. J. Bot., 53, 62-72.

Holbrook, N.M., 1995. Stem water storage. In: Gartner, B.L. (Ed.): Plant Stems: Physiology and Functional Morphology. Academic Press, San Diego, pp. 151-174.

Irvine, J., Grace, J., 1997. Continuous measurements of water tensions in the xylem of trees based on the elastic properties of wood. Planta, 202, 455-461.

Ježík, M., Blaženec, M., Střelcová, K., 2007. Intraseasonal stem circumference oscillations: their connection to weather course. Folia Oecologica, 34, 105-115.

Ježík, M., Blaženec, M., Střelcová, K., Ditmarová, L., 2011. Impact of the 2003-2008 weather variability on intra-annual stem diameter changes of beech trees at a submontane site in central Slovakia. Dendrochronologia, 29, 227-235.

Ježík, M., Blaženec, M., Letts, M.G., Ditmarová, L., Sitková, Z., Střelcová, K., 2014. Assessing seasonal drought stress response in Norway spruce (Picea abies (L.) Karst.) by monitoring stem circumference and sap flow. Ecohydrol DOI: $10.1002 /$ eco. 1536

Katerji, N., Hallaire, M., 1984. Reference measures for use in studies of plant water needs. Agronomie, 4, 999-1008.

Kučera, J., Cermak, J., Penka, M., 1977. Improved thermal method of continual recording the transpiration flow rate dynamics. Biol. Plant (Praha), 19, 413-420.

Lassoie, J.P., 1979. Stem dimensional fluctuations in Douglasfir stem in response to tree water status. For. Sci., 25, 132 144.

López-Bernal, A., Alcantara, E., Testi, L., Villalobos, F.J., 2010. Spatial sap flow and xylem anatomical characteristics in olive trees under different irrigation regimes. Tree Physiol., 30, 1536-1544.

Nadezhdina, N., 1988. Apple tree water relations and their optimization under conditions of southern Ukraine (in Russ.). PhD Thesis. Kiev, $166 \mathrm{p}$.

Nadezhdina, N.E., 1989. A physiological algorithm of woody plant irrigation control under air drought. Fiziologiaya rastenii, 36, 972-979. (In Russian.)

Nadezhdina, N., 1992. Apple tree water relations studied by means of the relative rate of water flow in the trunk xylem. Biol. Plant. (Praha), 34, 431-437.

Nadezhdina, N., 1998. Temperature gradients around a linear heater due to moving sap. In: Cermak J, Nadezhdina, N. (Eds): Proc. 4th Int. Workshop on Measuring sap flow in intact plants. Publishing House of Mendel University, Brno, Czech Republic, pp. 65-71.

Nadezhdina, N., 1999. Sap flow index as an indicator of plant water status. Tree Physiol., 19, 885-891.

Nadezhdina, N., 2000. Specificity of sap flow index for mist irrigation control. Acta Horticulturae, 537, 479-486.
Nadezhdina, N., 2009. Additional Information Derived from Detail Analysis of Raw Temperature Data Measured with the HFD-method. Acta Hortic., 846, 77-84.

Nadezhdina, N., Čermák, J., Nadezhdin, V., 1998. Heat field deformation method for sap flow measurements. In: Cermak, J., Nadezhdina, N. (Eds): Proceedings of the 4th international workshop on measuring sap flow in intact plants. Publishing House of Mendel University, Czech Republic, pp. 72-92.

Nadezhdina, N., Vandegehuchte, M.W., Steppe, K., 2012. Sap flow measurements based on Heat Field Deformation method. Trees, 26, 1439-1448.

Offenthaler, I., Hietz, P., Richter, H., 2001. Wood diameter indicates diurnal and long-term patterns of xylem water potential in Norway spruce. Trees, 15, 215-221.

Perämäki, M., Nikinmaa, E., Sevanto, S., Ilvesniemi, H., Siivola, E., Hari, P., Vesala, T., 2001. Tree stem diameter variations and transpiration in Scots pine: an analysis using dynamic sap flow model. Tree Physiol., 21, 889-897.

Sevanto, S., Vesala, T., Perämäki, M., Nikinmaa, E., 2002. Time lags for xylem and stem diameter variations in a Scots pine tree. Plant Cell Environ., 25, 1071-1077.

Sevanto, S., Hölttä, T., Markkanen, T., Perämäki, M., Nikinmaa, E., Vesala, T., 2005. Relationships between diurnal diameter variations and environmental factors in Scots pine. Boreal Environ. Res., 10, 447-458.

Sevanto, S., Nikinmaa, E., Riikonen, A., Daley, M., Pettijohn, J.C., Mikkelsen, T.N., Phillips, N., Holbrook, N.M., 2008. Linking xylem diameter variations with sap flow measurements. Plant Soil, 305, 77-90.

Vieira, J., Rossi, S., Campelo, F., Freitas, H., Nabais, C., 2013. Seasonal and daily cycles of stem radial variation of Pinus pinaster in a drought-prone environment. Agric. For. Meteorol., 180, 173-181.

Wang, Z., Yang, B., Deslauriers, A., Qin, C., He, M., Shi, F., Liu, J., 2012. Two phases of seasonal stem radius variations of Sabina przewalskii Kom. in northwestern China inferred from sub-diurnal shrinkage and expansion patterns. Trees, 6 , $1747-1757$.

Waring, R.H., Running, S.W., 1978. Sapwood water storage: its contribution to transpiration and effect upon water conductance through the stems of old-growth Douglas-fir. Plant Cell Eviron., 1, 131-140.

Zweifel, R., Item, H., Häsler, R., 2000. Stem radius changes and their relation to stored water in stems of young Norway spruce trees. Trees, 15, 50-57.

Zweifel, R., Item, H., Häsler, R., 2001. Link between diurnal stem radius changes and tree water relations. Tree Physiol., 21, 869-877.

Zweifel, R., Zimmermann, L., Zeugin, F., Newbery, D.M., 2006. Intra-annual radial growth and water relations of trees - implications towards a growth mechanism. J. Exp. Bot., 57, 1445-1459.

Zweifel, R., Drew, D.M., Schweingruber, F.H., Downes, G.M., 2014. Xylem as the main origin of stem radius changes in Eucalyptus. Funct. Plant Biol., 41, 520-534.

Received 12 September 2014 Accepted 8 December 2014

Note: Colour version of Figures can be found in the web version of this article. 